\title{
New spoligotyping pattern of Mycobacterium bovis isolates from farm animals in Turkey
}

\author{
Meriç Lütfi AVSEVER ${ }^{1}$, Cengiz ÇAVUŞOĞLU ${ }^{2}$, Öznur YAZICIOĞLU ${ }^{3}$, Seza ESKIIIZMİRLILER ${ }^{4}$, \\ Gülçin ERDAL ${ }^{3}$, Münevver Ziynet GÜNEN³ , Serra TUNALIGIL ${ }^{4}$, Bayram ALPARSLAN ${ }^{3}$, \\ Adil AKSOY ${ }^{1}$
}

\begin{abstract}
${ }^{1}$ Aksaray University, Eskil Vocation of High School, Laboratory and Veterinary Sciences, Aksaray; ${ }^{2}$ Ege University, Faculty of Medicine, Department of Medical Microbiology; ${ }^{3}$ Bornova Veterinary Control Institute, Pathology Laboratory; ${ }^{4}$ Bornova Veterinary Control Institute, Bacteriology Laboratory, İzmir, Turkey.
\end{abstract}

Summary: Mycobacterial diseases still have a global impact on human and animal health as well as being the cause of great economic losses. Mycobacterium bovis is the most important tuberculosis agent in animal husbandry, especially in cattle farming. This bacterium also plays a significant role in human infections as it is the second most important tuberculosis agent after Mycobacterium tuberculosis. In this work, internal organ samples of four cattle and two goats from six slaughterhouses in the Aegean region (Aydin, Manisa, Muğla, İzmir provinces) presented to the laboratory for tuberculosis diagnosis between 2010-2015 were used. Histopathologic examination and inoculations into Lowenstein-Jensen and BACTEC MGIT 960 liquid media were carried out from these samples. Genotypes of the isolates were determined by spoligotyping. All six isolates were M. bovis SIT 685, BOV. This genotype was previously reported from Argentina, Brazil, Germany, France, Ireland and Great Britain at a low frequency and is considered to be uncommon throughout the world. However, this pattern (SIT 685, BOV) from M. bovis isolated from farm animals in the Aegean region of Turkey shows homology with $M$. bovis isolates'spoligotyping results from humans in the same region. This result might indicate a possible animal to human transmission of $M$. bovis. On the other hand, this spoligotype (SIT 685, BOV) was also reported from human samples in the Marmara region of Turkey. Therefore, it can be assumed that this genotype affects a significant portion of the human population in Turkey. As a result of this work, SIT 685, BOV of M. bovis which causes disease in farm animals in Turkey, is reported for the first time, data possibly strengthening the zoonotic aspect of the agent is acquired and attention is drawn to the prevalence of $M$. bovis SIT 685, BOV in people in Turkey.

Keywords: Aegean region, farm animals, Mycobacterium bovis, SIT 685- BOV, spoligotyping.

\section{Türkiye'deki çiftlik hayvanlarından izole edilen Mycobacterium bovis izolatlarına ait yeni spoligotiplendirme paterni}

Özet: Mikobakteri türlerinin neden olduğu hastalıklar dünyada hala ciddi bir sorundur ve büyük ekonomik kayıplara sebep olmaktadır. Hayvancılık sektöründe başta sığırlar olmak üzere, pek çok ruminantta hastalık oluşturabilen en önemli mikobakteri türü Mycobacterium bovis'tir. Bu etken insanlardaki tüberküloz hastalığının etiyolojisinde de rol oynar ve insanlarda Myobacterium tuberculosis'ten sonraki en önemli tüberküloz etkenidir. Bu çalışmada, 2010-2015 yılları arasında, Ege bölgesindeki (Aydın, Manisa, Muğla, İzmir illeri) altı mezbahadan tüberküloz şüphesi için laboratuvara gönderilmiş dört sığır ve iki keçiye ait iç organ örnekleri kullanıldı. Organ örneklerinin histopatolojik muayenesi ile Lowenstein-Jensen ve BACTEC MGIT 960 sıvı besi yerlerine bakteriyel ekimleri yapıldı. Üreyen bakteriler spoligotiplendirme yöntemiyle genotiplendirildi. Altı izolatın da M. bovis SIT685, BOV olduğu görüldü. Bu genotip Arjantin, Brezilya, Almanya, Fransa, İrlanda ve İngiltere (GBR)'den az sayıda bildirilmiş olup, dünyada yaygıın olarak görülmemektedir. Ayrıca, Ege bölgesindeki çiftlik hayvanlarından izole edilen M. bovis'e ait bu patern (SIT 685, BOV) Ege Bölgesi'nde insanlardan izole edilen M. bovis izolatlarına ait spoligotiplendirme paternleri ile homoloji göstermektedir. Bu veri $M$. bovis'in hayvanlardan insanlara bulaştığı görüşüne destek verebilir. Diğer taraftan bu spoligotip (SIT 685, BOV) Marmara bölgesindeki insanlarda da bildirilmiş olup, Türkiye'deki insan populasyonunun büyük bir bölümünü etkiliyor gibi görünmektedir. Sonuç olarak bu çalışmada, Türkiye'deki çiftlik hayvanlarında hastalık oluşturan M. bovis'e ait SIT 685, BOV spoligotiplendirme paterni ilk kez bildirilmiş, etkenin zoonotik yönünü güçlendirecek olası veriler elde edilmiş ve M. bovis SIT685, BOV'un ülkemiz insanlarındaki yaygınlığına dikkat çekilmiştir.

Anahtar sözcükler: Çiftlik hayvanları, Ege bölgesi, Mycobacterium bovis, SIT 685-BOV, spoligotyping. 


\section{Introduction}

Tuberculosis is a chronic infectious and zoonotic bacterial disease characterized with caseous and caseocalcareous tubercules in many organs and tissues, especially lungs. Most common Mycobacterial agents are; M. tuberculosis in humans, M. bovis in cattle and M. avium in birds (5). M. bovis, is a member of the M. tuberculosis complex. Bovine tuberculosis is a notifiable disease in Turkey according to the law on veterinary services, plant health, food and feed $(1,2)$.

Research on the incidence of bovine tuberculosis in Turkey is limited. In the " Seroepidemiology of bovine tuberculosis with ELISA" project which was carried out between 1996-1997. 12.904 bovine serum samples were tested and prevalence of tuberculosis was found to be 10 $\%$. In other research projects based on tuberculin testing, individual and herd prevalence were found to be low in Thrace (Edirne, Kırklareli, Tekirdağ provinces) whereas herd prevalence in Sakarya and Tokat as well as individual prevalence in Kastamonu and Elazıg were found to be high. Annual changes in prevalence of tuberculosis is commonplace in Turkey due to the large animal population, diversity of geographical distribution and excessive animal movements (3).

M. bovis'zoonotic character is also important. World Health Organization (WHO) reported 7000 new human turberculosis cases each year due to $M$. bovis but the true incidence was predicted to be eight times higher (22). Humans are reported to be capable of being reservoirs of $M$. bovis. Data on the incidence of human cases of $M$. bovis is also limited (22). In most cases, clinical and pathological properties of $M$. bovis cannot be distinguished from $M$. tuberculosis infections $(8,12,18)$. For this reason, incidence of $M$. bovis remains unknown in many patients and necessary strategies for protection and treatment cannot be developed (18).

Extrapulmonary cases caused by $M$. bovis are related to the consumption of infected milk. As pasteurization practices became common and dairy industry developed; alimentary infection with milk consumption lost its importance. Still, respiratory infection is reported in meat industry and slaughterhouse workers (19).

Gold method for M. bovis diagnosis is culture of the bacterium while typing of the isolates is generally based on molecular methods. Although Restriction Fragment Length Polymorphism (RFLP) is still commonly used; spoligotyping (Spacer Oligonucleotide Type Analysis) based on the PCR amplification of Direct Repeat (DR) region has become a preferred choice for the genotyping of the agent (10). Spoligotyping is reported to be a more economic, rapid and easy when compared to $\operatorname{RFLP}(4,9$, 10). Spoligotyping is based on the polymorphism of DR regions of Mycobacterial DNA. DR regions of $M$. tuberculosis complex are formed with non-repetitive spacer regions embedded between repetitive sequences of varying numbers. After DNA extraction, amplification of all DR region is carried out with PCR. Amplicons are hybridized with membrane anchored oligonucleotides and made visible with streptavidin peroxidase autoradiography (15). Numeric spoligotyping results are developed into serial numbers defining the hybridization model.

The aim of this work is to report a new spoligotyping patterns of $M$. bovis isolates from farm animals of the Aegean region and to draw attention to the zoonotic importance and prevalence of this spoligotype.

\section{Materials and Methods}

Internal organ samples (lungs, pulmonary-associated lymph nodes, spleen, liver and kidneys) used in this work belonged to four cattle and two goats. They were obtained from six slaughterhouses in the Aegean Region (Aydın, Manisa, Muğla, Izmir provinces) and were presented to the laboratory between 2010-2015 for tuberculosis diagnosis.

Histopathology: Lungs and pulmonary-associated lymph nodes from all animals with gross tuberculosis-like lesions and also other organ samples such as spleen, liver and kidneys from one goat and one cattle were subjected to histopathological examination. Tissue samples were fixed in 10\% neutral buffered formalin. After processing with standard histological techniques, samples were embedded in paraffin wax, sectioned at 4-5 $\mu \mathrm{m}$ thickness and stained with Hematoxylin and Eosin (HE) for histopathological examinations and also by the ZiehlNeelsen (ZN) technique for identification of acid-fast bacteria (14).

Culture of M. Bovis: Tissue samples (5-10 g) taken asceptically from lesions in the lungs and pulmonary associated lymph nodes were homogenized with a homogenizer (Stuart Homogenizer SHM1, USA). Homogenized tissues were processed by the conventional $\mathrm{N}$-acetyl-L-cysteine-sodium hydroxide (NALC-NaOH) method (11). After decontamination, smears were prepared by the auramine-rhodamine acid-fast staining method. Decontaminated specimens were inoculated to Lowenstein-Jensen (LJ) solid medium and BACTEC MGIT 960 liquid medium (Becton, Dickinson and Company, USA) and incubated eight weeks for growth detection.

Spoligotyping: Spoligotyping was carried out according to the manufacturer's (Spoligotyping Kit; Isogen LifeScience, The Netherlands) instructions. DNA was extracted from the isolates and positive controls $(M$. tuberculosis $\mathrm{H} 37 \mathrm{Rv}$ and $M$. bovis BCG strains) with boiling and ultrasonic bath methods. $5 \mu 1$ of the DNA extract was used as the template. PCR primers, initially designed by Kamerbeek et al. (10) and used by Aranaz et al. (4), were DRa 5'-GGTTTTGGGTCTGACGAC-3' and biotin conjugated DRb 5'- CCGAGAGGGGACGGAA AC-3'. These primers were used in the amplification of 
the DR region which would be subjected to spoligotyping. $\mathrm{dH}_{2} \mathrm{O}$ was used as the negative control. PCR master-mix $(50 \mu \mathrm{l})$ consisted of; $3 \mathrm{U}$ Hot Star Taq DNA polymerase $(0.6 \mu \mathrm{l}) 10 \mathrm{X}$ buffer $(5 \mu \mathrm{l}), 25 \mathrm{mM} \mathrm{MgCl}_{2}(5 \mu \mathrm{l}), 20 \mathrm{pM}$ DRa primer $(4 \mu \mathrm{l}), 20 \mathrm{pM} \mathrm{DRb}$ primer $(4 \mu \mathrm{l})$, template DNA $(5 \mu \mathrm{l}), 2.5 \mathrm{mM}$ dNTP mix $(4 \mu \mathrm{l})$ and nuclease free $\mathrm{dH}_{2} \mathrm{O}(22.4 \mu \mathrm{l})$. Amplification parameters were $15 \mathrm{~min}$. pre-denaturation in $95^{\circ} \mathrm{C}$ followed by, 30 cycles of $1 \mathrm{~min}$ denaturation in $95^{\circ} \mathrm{C}, 1 \mathrm{~min}$ annealing in $55^{\circ} \mathrm{C}$ and $45 \mathrm{sec}$. extension in $72^{\circ} \mathrm{C}$. Final extension was $10 \mathrm{~min}$. in $72^{\circ} \mathrm{C}$ (Applied Biosystems Veriti 96-Well Thermal Cycler, USA). Amplified PCR product was hybiridized onto the oligonucleotide anchored nitrocellulose membrane with a mini-blotter. Hybiridized DNA was detected by chemoluminescence. After incubation with Amersham streptavidin-horseradish peroxidase (GE Healtcare Life Science, UK) and detection with Amersham ECL (Enhanced Chemo-luminescence) Detection Reagents (GE Healtcare Life Science, UK), hybrid regions were made visible as black squares. Spoligotypes were recorded in the SpolDB4 database in http://www.pasteurguadeloupe.fr and converted from a binary format to a 15 digit octal code. They were compared to other recorded strains in the database.

\section{Results}

In all animals, tuberculosis-like lesions in the lungs consisted of multiple variable sized white solid or yellowish caseous nodules often with mineralization, accompanied with extensive areas of consolidation with especially caudo-dorsal distribution (Figures 1, 2). Pulmonary-associated lymph nodes were enlarged and frequently showed caseo-calcified nodules (Figures 3, 4). Also, similar nodular lesions had disseminated to the liver in one cattle and to the liver and kidneys in one goat, together with serosal thickenings.

Microscopically, the lungs and pulmonary-associated lymph nodes showed predominantly the presence of large, thickly encapsulated granulomas with centric or multicentric areas of caseous necrosis and often mineralization (Figures 5,6). Necrotic centres were surrounded by a rim of epithelioid macrophages and multinucleated Langhan's giant cells admixed with lymphocytes (Figure 6). Acidfast bacilli were found in moderate to large numbers within the necrotic areas and in smaller numbers within macrophages and giant cells (Figures 7,8). The lungs also contained granulomas at various stages of development from small, irregular accumulations of epithelioid macrophages sometimes mixed with multinucleated giant cells to variable sized granulomas with central dense aggregates of neutrophils, and to solid encapsulated granulomas with or without small necrosis. Small, irregular accumulations of epithelioid macrophages were also seen in the lymph nodes. They had few or no acid-fast bacilli. In two generalized cases, tuberculous lesions in other organs also consisted of caseonecrotic granulomas with mineralization and serosal diffuse granulomatous infiltrations.

After inoculations on Lowenstein-Jensen and BACTEC MGIT 960 Media from lungs and pulmonary associated lymph nodes; growth on Lowenstein-Jensen media and positive signal from the BACTEC MGIT 960 system was observed. Six isolates of $M$. bovis were determined to be $M$. bovis SIT 685, BOV by spoligotyping. An image of the spoligotyping study is supplied in Figure 9.

\section{Discussion and Conclusion}

Caseous necrosis and calcification have been reported as common features of the granulomas encountered in natural $M$. bovis infections (13). In our study, encapsulated caseonecrotic and mineralized granulomas also formed the majority of tuberculous lesions in the lungs, with the existence of granulomas in different developmental stages, similar to the findings of Menin et al. (16) reporting that the most of the tuberculosis lesions observed in asymptomatic cattle naturally infected with $M$. bovis were in the chronic stage of development. Tuberculous granulomas in pulmonary-associated lymph nodes corresponded to the Stage III (necrotic) and Stage IV (necrotic and mineralized) granulomas of Wangoo et al. (21) describing four developmental stages of tuberculous granulomas in the lymph nodes of calves experimentally infected with $M$. bovis. Granulomas corresponding to stage I (initial) were also often found. Additionally, the high frequency of the lesions in the respiratory tract could suggest that the main transmission route of $M$. bovis was aerogeous in these cases, such as the findings of Menin et al. (16).

M. bovis isolates reported in the SITVIT WEB database were gathered under 5 clades which are BOV, BOV_1, BOV_2, BOV_3 and BOV_4 CAPRAE. Various spoligotypes exist within these clades. According to SITVIT WEB database, BOV_2 is the most common clade and SIT 683 (1855) within this clade is the most reported spoligotype around the world. SIT 679 (429), SIT 676 (177) spoligotypes are other common types within this clade. Most of these strains were reported from Ireland, United Kingdom and to a lesser degree from Argentina. BOV_1 is the second most common clade around the world. It was reported from France, Brazil, Argentina as well as the Netherlands, Germany and South Africa. The most common spoligotypes within this clade are SIT 481 (498), SIT 691(195) and SIT 665 (130). BOV clade which includes the SIT 685 spoligotype is the third most common in the world. BOV_4 CAPRAE is the fourth most common and affects goats mostly. BOV_3 clade is the least common; mostly it is reported from Argentina and Ireland. Approximately, $80 \%$ of these reports indicate the SIT 479 (104) spoligotype. As SITVIT WEB is based 

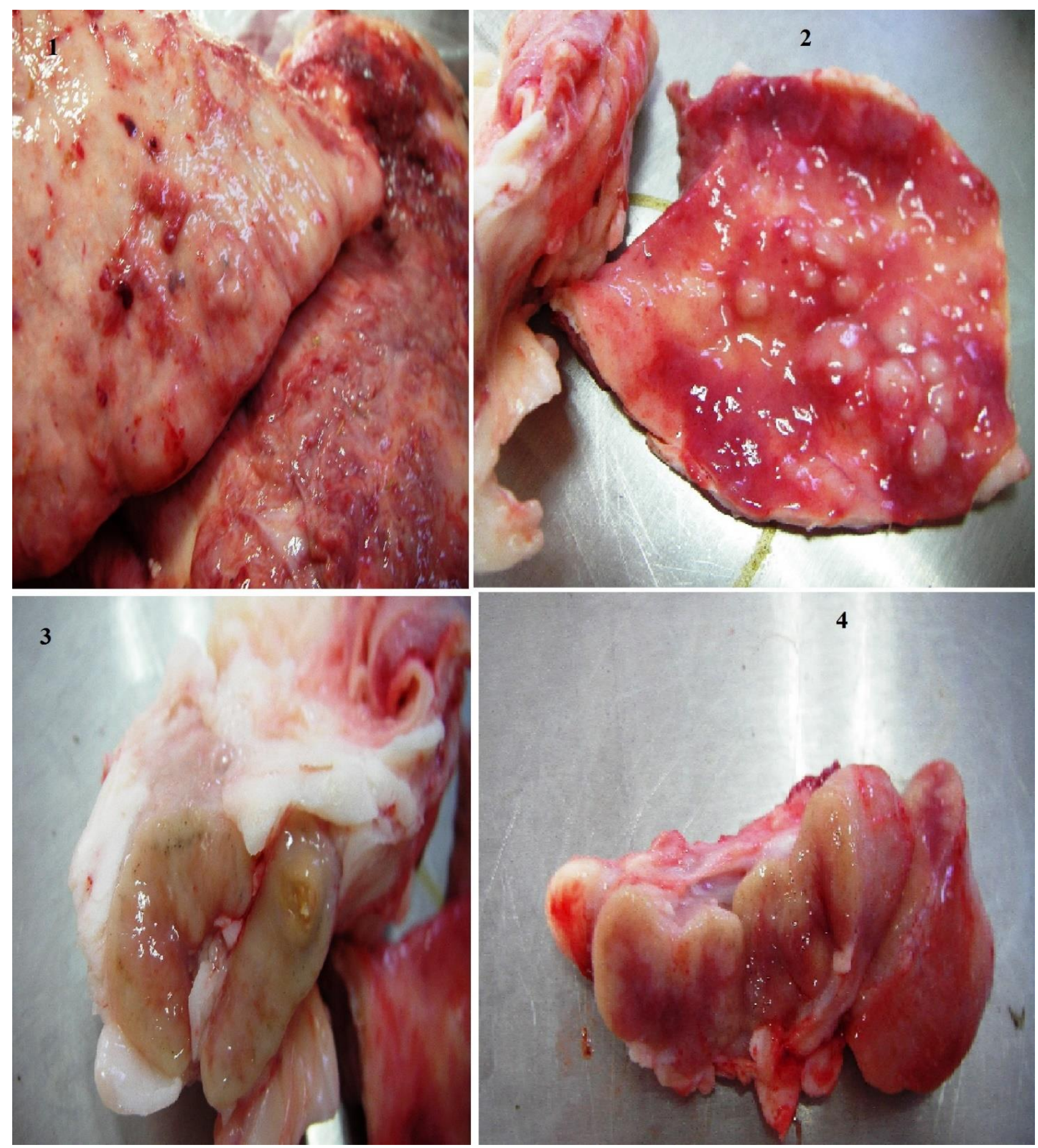

Figures 1-4. Gross tuberculous lesions in lungs and pulmonary-associated lymph nodes. 1. Nodular lesions and extensive consolidation in the caudal lobes of the lung. 2. A number of white solid tuberculous nodules in the rigth middle lobe. 3. A caseo-calcified nodule in lymphnode. 4. Pale coloured areas of cellular infiltrations in the cut surfaces of enlarged lymph node.

Şekil 1-4. Akciğer ve akciğer lenf düğümlerinde makroskopik tüberküloz lezyonları. 1. Akciğerin kaudal loblarında nodüler lezyonlar ve yaygın konsolidasyon. 2. Sağ orta akciğer lobunda çok sayıda beyaz solid tüberküloz nodülleri. 3. Lenf düğümünde kazeo-kalsifiye bir nodül. 4. Büyümüş lenf düğümünün kesit yüzlerinde soluk renkli hücresel infiltrasyon sahaları. 

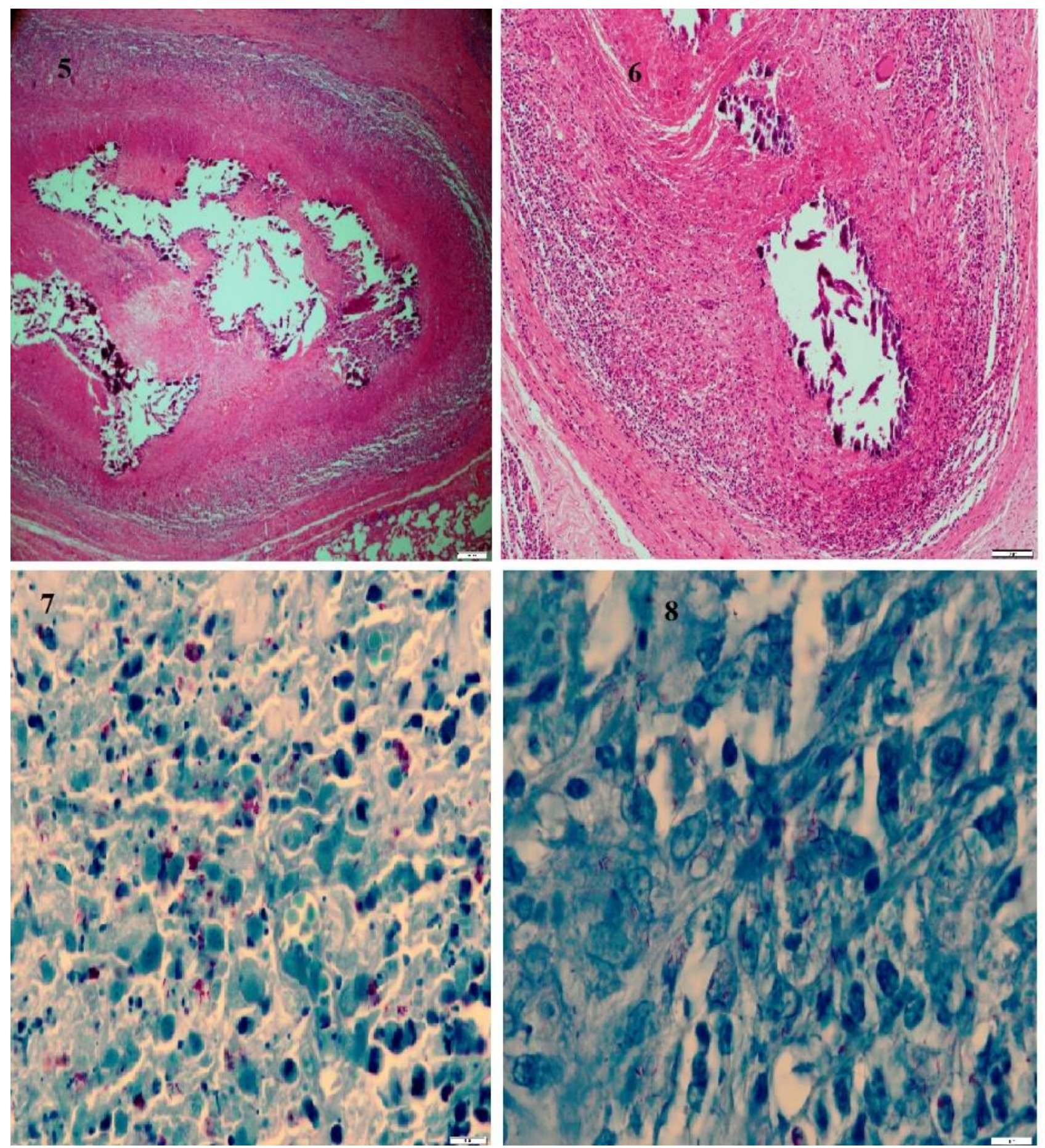

Figures 5-8. Microscopical tuberculous lesions in the lungs. 5. Encapsulated caseo-necrotic and mineralized granuloma. HE. Bar=200 $\mu \mathrm{m}$. 6. A rim of epithelioid macrophages and multinucleated Langhan's giant cells admixed with lymphocytes surrounding the necrotic core. HE. Bar $=100 \mu \mathrm{m}$. 7. Acid-fast bacilli extracellularly within the necrotic areas. ZN. Bar=10 $\mu \mathrm{m}$. 8. Acid-fast bacilli within epithelioid macrophages surrounding the necrosis. ZN. Bar=10 $\mu \mathrm{m}$.

Şekil 5-8. Akciğerlerde mikroskopik tüberküloz lezyonları. 5. Bağdoku ile kapsüllenmiş kazeo-nekrotik ve kireçlenmiş granuloma. HE. Bar=200 $\mu$ m. 6. Nekrotik merkezi çevreleyen lenfositler ile karışık epitelioid makrofajlar ve Langhan's dev hücrelerinden oluşan hücresel infiltrasyon. HE. Bar=100 $\mu$ m. 7. Nekrotik saha içinde aside-dirençli basiller. ZN. Bar=10 $\mu \mathrm{m}$. 8. Nekrozu kuşatan epitelioid makrofajlarda aside dirençli basiller. ZN. Bar $=10 \mu \mathrm{m}$. 


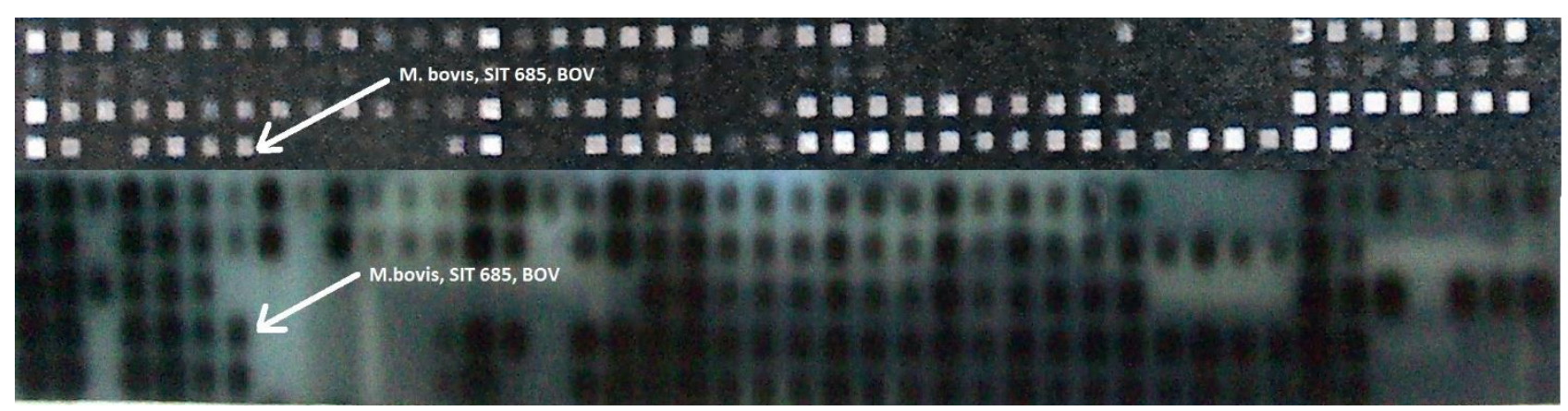

Figure 9. Defining pattern for the SIT 685, BOV where hybridization of spacer regions 3,8-12,16 and 39-43 were not observed. Şekil 9. SIT 685, BOV için tanımlayıcı patern, 3, 8-12, 16 ve 39-43 nolu spacer bölgelerinde hibridizasyon gözlenmedi.

on voluntary notifications, it can be assumed that it does not give an extensive outlook on the epidemiology of bovine tuberculosis on a global scale.

There have been two reports on spoligotyping of bovine $M$. bovis isolates in Turkey. Tuzcu et al. (20), in a report on $M$. bovis strains isolated from cattle slaughtered in Çukurova region, have found that 11 of the strains were M. bovis SIT 683 (SB0140), 4 of them were ST 685 (SB288), 7 were M. bovis subsp. caprae ST 647 (SB0418) while 2 strains' spoligotype pattern (220003777377600, 674077777777600) did not match any of the strains in the database. In another study carried out by Yardimc1 et al. (23) in Central Anatolia Region, patterns were as follows; AN5 456477777777600 (not found in the database), Ank-2 676773577777600 (not found in the database), Ank-1 676763677777600 (SIT 695; BOV) and Ank-3 616773777777600 (SIT 665; BOV_1). Ank-1 was also reported in the SITVIT WEB database in 5 countries and 11 isolates. They were BEL(1) BRA(1) DEU(2) ESP(1) $\operatorname{MEX}(2) \operatorname{NLD}(3)$ and USA(1), respectively. Ank-3 is even more common and was reported in 12 countries and 130 strains. These were: ARG(1) BEL(19) BRA(8) DEU(3) ESP(3) FRA(71) GBR(2) ITA(9) NLD(3) REU(2) TUN(2) ZAF(2), respectively.

SIT683 (SB0140) genotype found by Tuzcu et al. (20) in Çukurova is the most common genotype in the world. On the other hand, SIT 685 which was observed to be the most dominant type in the Aegean region is reported to be rare around the world. Although there are only a limited number of isolates in the central Anatolian study; it was obvious that their genotypes were different from the isolates in the Aegean and Çukurova regions.

This situation shows that the agent has variations among regions. For example, as well as SIT 683 being the dominant strain in our country, SIT 685, a rare spoligotype in the world, is also one of the common genotypes in Turkey. To fully understand the prevalence and importance of this type in Turkey, genotyping studies should be carried out in other regions and more data regarding $M$. bovis should be made available.

In this work, the SIT 685, BOV spoligotyping pattern obtained from cattle and goats was previously not reported from Turkey but 11 isolates in 6 countries were found to have this pattern; these were Argentina (2), Brazil (1), Germany (3), France (1), Ireland (1) and Great Britain (GBR) (3), respectively. Although this might be an indication of transmission of the spoligotype by international animal trade, further evidence and detailed research is necessary to reach a conclusion. Within all human TB cases the average rate of $M$. bovis infections were reported to be $<1.4 \%$, for non-African countries and $2.8 \%$ for the African continent. Among the tuberculosis cases in Europe, the average rate of $M$. bovis infections was $0.4 \%$ with no European country exceeding $2.3 \%$. In all regions outside Africa, zoonotic tuberculosis incidence was either $1 / 100.00$ or below, while in Africa this rate was approximately 7/100.000 (16).

In a spoligotyping study carried out by Çavusoglu et al. (unpublishing) between 2009-2014 in the Mycobacteriology Laboratory of Aegean University Faculty of Medicine, out of 470 M. tuberculosis complex strains, 13 were found to be $M$. bovis and within all human M. tuberculosis strains, $M$. bovis was found at a rate of 2.9\%. 9 of these 13 M. bovis strains were ST685, 1 was ST820 and another was ST1118. The remaining two spoligotypes did not correspond with any other strain in the database.

The resemblance between strains of $M$. bovis obtained from animals and humans in the same region might be supportive of animal to human transmission. On the other hand, the pattern from the Aegean Region (SIT $685, \mathrm{BOV})$, is different from the results of the study carried out by Aslan et al. (6) with human isolates. In that work, researchers reported the isolation of M. bovis with the octal code of 676773777777600 (SIT: 696, BOV) from humans in the Mersin province. These findings show a regional difference between humans in Turkey as well (7). Still, the pattern found in this study (SIT 685, BOV) corresponds with the findings of the study by Koksalan et al. (Personal interview, unpublished) in the Marmara region.

15 of 46 human origined $M$. bovis isolates in Koksalan et al's study were found to be SIT 685 which was the most common $M$. bovis spoligotype of human 
origin. Thus, it can be said that this genotype is not exculsive to the Aegean Region but can also be found in the Marmara region as well. Marmara and Aegean regions have the highest population rate in Turkey. Therefore, the spoligotype has some significance in terms of public health.

There are three important questions about M. bovis epidemiology in Turkey that await answers: 1 . What is the genotype distribution and possible transmission routes and sources of M. bovis in animals in Turkey? 2. What is the transmission routes and clinical presentation of $M$. bovis infections in humans? 3. Does the $M$. bovis genotype distribution of human samples in Turkey bear a resemblance to animals' or could there be a more virulent or easily transmissible $M$. bovis spoligotype more prevalent in humans? To provide answers for these questions, collaborative research by scientists employed in medicine and veterinary medicine fields is a necessity.

As a result of this work, internal organ samples of 4 cattle and 2 goats from the Aegean Region were investigated for tuberculosis with histopathologic, bacteriologic and molecular methods and the strains were found to be $M$. bovis SIT 685, BOV. Also, zoonotic quality of $M$. bovis and its possible effects on a large part of human population in Turkey is emphasized.

\section{References}

1. Anonim (1978): Sığır Tüberkülozu Yönetmeliği. TC Gıda, Tarım ve Hayvancılık Bakanlığı, Veteriner İşleri Genel Müdürlüğü, Yönetmelik sayısı 12, Lalahan Zootekni Araştırma Enstitüsü Deneme Çiftl. Md. Basım Servisi, Ankara.

2. Anonim (1995): Veteriner Hizmetleri, Bitki Sa ̌̆lı̆̆l, Glda ve Yem Kanunu. Tarım ve Köyişleri Bakanlığı, Koruma ve Kontrol Genel Müdürlüğü, Ankara.

3. Anonim (2015): Siğır tüberkülozu. http://www.tarim.gov.tr/Konular/Veteriner-Hizmetleri/ Hayvan-sagligi[2]. 02.01.2015.

4. Aranaz A, Liebana E, Mateos A, et al. (1996): Spacer oligonucleotide typing of Mycobacterium bovis strains from cattle and other animals: A tool for studying epidemiology of tuberculosis. J Clin Microbiol, 36, 2734-2740.

5. Arda M, Minbay A, Leloğlu N, et al. (1997): Özel Mikrobiyoloji, 180, 4. baskı, Medisan Yayın Serisi No: 26, Ankara.

6. Aslan G, Kuyucu N, Çalıkoğlu N, et al. (2009): Mycobacterıum bovis'in etken olduğu tüberküloz olgulart. Ankem derg, 23, 182-187.

7. Aslan G, Kuyucu N, Aydın E, et al. (2010): Mycobacterium bovis bcg suşunun neden olduğu fatal disemine enfeksiyon olgusu ve izolatın spoligotiplendirme ile tanımlanmasi, Mikrobiyol Bul, 44, 297-302.

8. Baker MG, Lopez LD, Cannon MC, et al. (2006): Continuing Mycobacterium bovis transmission from animals to humans in New Zealand, Epidemiol Infect, 34, 1068-1073

9. De La Salmoniere YOG, Li HM, Torrea G, et al. (1997): Evaluation of spoligotyping in a study of the transmission of Mycobacterium tuberculosis. J Clin Microbiol, 35, 2210-214.
10. Kamerbeek J, Schouls L, Kolk A, et al. (1997): Simultaneous detection and strain differentiation of Mycobacterium tuberculosis for diagnosis and epidemiology. J Clin Microbiol, 35, 907-914

11. Kent PT, Kubica GP (1985): Public health mycobacteriology. A guide for a level III laboratory. Centers for Disease Control, Atlanta, GA.

12. Lari N, Rindi L, Bonanni D, et al. (2006): Molecular analysis of clinical isolates of Mycobacterium bovis recovered from humans in Italy. J Clin Microbiol, 44, 42184221.

13. Liebana E, Johson L, Gough J, et al. (2008): Pathology of naturally occurring bovine tuberculosis in England and Wales. Vet J, 176, 354-360.

14. Luna LG (1968): Manual of Histologic Staining Methods of the Armed Forced Institute of Pathology, Third edition, McGraw-Hill Book Company, Newyork, ABD.

15. Marchetti G, Gori A, Catozzi L, et al. (1997): Comparison of spoligotyping vs RFLP DNA Fingerprinting analysis in M. Tuberculosis epidemiological typing. 4. Conference on Retroviruses and Opportunistic Infections, Washington DC, p.184.

16. Menin Á, Fleith R, Reck C, et al. (2013): Asymptomatic cattle naturally infected with Mycobacterium bovis present exacerbated tissue pathology and bacterial dissemination. PLoS One, 8, e53884.

17. Muller B, Durr S, Alonso S, et al. (2013): Zoonotic Mycobacterium bovis-induced tuberculosis in humans. Emerg Infect Dis, 19, 899-908.

18. Rodwell TC, Moore M, Moser KS, et al. (2008): Tuberculosis from Mycobacterium bovis in binational communities, United States, Emerg Infect Dis, 14, 909-916.

19. Thoen C, Lobue P, de Kantor I (2006): The importance of Mycobacterium bovis as a zoonosi. Vet Microbiol, 112, 339-345.

20. Tuzcu N, Kayar B, Uysal EB, et al. (2015): Türkiye'de sığırlardan izole edilen $M$. bovis suşlarının spoligotiplendirmesi, 7. Ulusal Mikobakteri Kongresi, Mersin.

21. Wangoo A, Johnson L, Gough J, et al. (2005): Advanced granulomatous lesions in Mycobacterium bovis-infected cattle are associated within crease dexpression of type I procollagen, gammadelta (WC1+) T cells and CD 68+ cells. J Comp Pathol, 133, 223-234.

22. Wei CY, Hsu YH, Chou WJ, et al. (2004): Molecular and histopathologic evidence for systemic infection by Mycobacterium bovis in a patient with tuberculous enteritis, peritonitis, and meningitis: A case report, Kaohsiung, J Med Sci, 20, 302-307.

23. Yardımcı H, Ünal CB, Ataseven L, et al. (2007): Siğır tüberkülozunun PCR ile tanisl ve Mycobacterium bovis'in spoligotiplendirme yöntemi ile genotiplendirilmesi. Ankara Üniv Vet Fak Derg, 54, 183-189.

Geliş tarihi: 30.11.2015 / Kabul tarihi: 22.03.2016

\section{Address for correspondence:}

Asist. Prof. Meric Lütfi AVSEVER

Aksaray University, Eskil Vocation of High School, Laboratory and Veterinary Sciences. Aksaray/Turkey. email:lutfiavsever@gmail.com 